Tomasz Grzegorz Grosse

Institute of European Studies, University of Warsaw

DOI: $10.19195 / 2450-274 X .2 .11$

\title{
The European Parliament and the negotiation of the Multiannual Financial Framework
}

Abstract: The paper examines the role of the European Parliament in the process of adopting the MFF for 2014-2020. This particular case is attention-worthy for at least two reasons: firstly, it demonstrates the actual political role of the EP in relation to fiscal policy, where this institution's power is much weaker than in other regulatory matters. Secondly, it illustrates the role of the EP during a period of economic crisis, and therefore at a time when the impact of the intergovernmental factor on European policy was much increased. In doing so, the author will verify three hypotheses. The first is that although the legislative competences of the EP are rising steadily, this does not mean that the relative power of this institution is also on the ascent, i.e. to a comparison with intergovernmental institutions. Secondly, the author is to consider whether the activity of the EP is not primarily used for the purposes of political legitimisation and marketing. Thirdly, he is to verify the claim that the EP is a platform for the development of supranational elites.

Keywords: European Parliament, Multiannual Financial Framework, economic crisis, relative power, political legitimisation and marketing, supranational elites

\section{Parlament Europejski a negocjacje nad Wieloletnią Perspektywą Finansową}

Abstrakt: Celem artykułu jest analiza roli Parlamentu Europejskiego (PE) w procesie stanowienia Wieloletnich Ram Finansowych na lata 2014-2020. Autor podejmuje próbę weryfikacji trzech hipotez, które niekiedy występują w literaturze dotyczącej parlamentaryzmu europejskiego. Po pierwsze, wprawdzie kompetencje ustawodawcze PE systematycznie rosną, jednak nie oznacza to, że wzrasta władza polityczna tej instytucji w UE. Dotyczy to zwłaszcza władzy względnej, a więc w odniesieniu do tej, jaką dysponują instytucje międzyrządowe. Po drugie, aktywność PE służy przede wszystkim celom legitymizacyjnym w UE. Po trzecie, PE jest platformą dla rozwoju elit europejskich lub ponadnarodowych.

Słowa kluczowe: Parlament Europejski, Wieloletnia Perspektywa Finansowa, kryzys gospodarczy, władza względna, legitymizacja polityczna, elity transnarodowe. 


\section{Introduction}

Since 1988 the European Community, and now the European Union, determines the Multiannual Financial Framework (MFF). The period 2014-2020 is therefore the fifth multiannual framework of the European budget. The opinion prevails among the scholars that the powers of the European Parliament (EP) steadily increased with subsequent amendments to the EU treaties. But it is not so certain in relation to the area of fiscal policy ${ }^{1}$. Under the Lisbon Treaty the EP has less power in regard to MFF than, e.g. in the matter of the adoption of the annual budget of the Union. In both cases, the national governments are the main players, at least according to some scholars ${ }^{2}$. Other scholars claim that the Treaty hinders the EP's ability to introduce amendments to the governments' decisions and systemic reforms with regard to the $\mathrm{MFF}^{3}$. In this way, the Treaty protects the status quo in terms of sources of EU revenues and impedes the Parliament's efforts to increase the size of the MFF.

The important role of the member states in the process of negotiations of the MFF is best evidenced by the role of the European Council. The Council does not have formal legislative powers, but it is very deeply involved in the process. Such was also the case during the negotiations on the MFF 2014-2020. It were precisely the heads of state or heads of government, and therefore politicians of the highest level in Europe, who took all major decisions on the new financial perspective. As a consequence, the decisions taken reflect the will of governments, and particularly of the net contributors to the EU budget. This time, pursuant to the Council's wishes, the size of the EU budget was for the first time reduced in comparison with the previous perspective (both measured in constant prices). It is also interesting to note that the EU Council adopts the MFF unanimously, which highlights the importance of each country (because any country could potentially veto undesirable decisions.) The Parliament's role is limited to granting consent to the ultimate outcome of the intergovernmental negotiations. This puts it in a much worse position in relation to the national governments.

Moreover, apart from formal and procedural issues, it is also the informal considerations that count during the negotiations. And the most important of these considerations is the political mandate to take decisions with regard to the EU funds. The vast majority of the EU budget revenue comes from the national budgets (74\%). The governments therefore have a much stronger mandate than the EP in order to decide how to spend their own taxpayers' money. The discussions over the EU budget are among the few EU matters that make headlines in the na-

${ }^{1}$ G. Majone, "From Regulatory State to a Democratic Default", JCMS, 52(6), 2014, p. 1217.

2 Ch. J. Schneider, "Globalizing Electoral Politics. Political Competence and Distributional Bargaining in the European Union”, World Politics, 65(3), 2013, pp. 452-490.

${ }^{3}$ J. Wehner, "Institutional Constraints on Profligate Politicians: The Conditional Effect of Partisan Fragmentation on Budget Deficits", Comparative Political Studies, 43(1), 2010, 208-229. 
tional media and are exploited by politicians for electoral purposes ${ }^{4}$. At the same time, the increasing politicization of these negotiations, i.e. their integration into the national electoral politics makes it difficult to increase the scale and to implement structural reform of the EU finances ${ }^{5}$. It is associated with the phenomenon of constraining dissensus with regard to the European integration ${ }^{6}$. Growing euroscepticism in the member states means that the hitherto existing consensus of the European society in favour of integration has all but disappeared. For this reason, it is much more difficult to justify any proposed increase of the EU budget. The attempts at communitarisation in the matter of the budget are also increasingly difficult, including the matter of the introduction of European taxes or handing power over deciding the budget to the EP.

In addition, the role of national governments and intergovernmental institutions in the EU has increased significantly during the eurozone crisis (after 2010). The EP seemed "withdrawn into the background", at least in terms of anti-crisis measures ${ }^{7}$. Anti-crisis actions taken by the EU weakened the national parliaments' control over budget policy, because they transfer some of the powers regarding national fiscal policy to European institutions. However, they only minimally include the EP in the new procedures of economic governance, which results in increasing the democratic deficit in Europe ${ }^{8}$. Taking into account these processes and their evaluation by scholars, I intend to examine in my article the role of the European Parliament in the process of adopting the MFF for 2014-2020. This particular case is attention-worthy for at least two reasons: firstly, it demonstrates the actual political role of the EP in relation to fiscal policy, where this institution's power is much weaker than in other regulatory matters'. Secondly, it illustrates the role of the EP during a period of economic crisis, and therefore at a time when the impact of the intergovernmental factor on European policy was much increased ${ }^{10}$.

${ }^{4}$ Ch. J. Schneider, op. cit.

5 P. De Wilde, "Politicisation of the EU Budget: Conflict and the Constraining Dissensus", West European Politics, 35(5), 2012, pp. 1075-1094.

${ }^{6}$ L. Hooghe, G. Marks, "A Postfunctionalist Theory of European Integration: From Perspective Consensus to Constraining Dissensus", British Journal of Political Science, 39(1), 2009, pp. 1-23.

7 D. Hodson, Governing the Euro Area in Good Times and Bad, Oxford 2011; U. Puetter, "Europe's deliberative intergovernmentalism: the role of the Council and European Council in EU economic governance", Journal of European Public Policy, 19(2), 2012, pp. 161-178; D. Dinan, "Governance and Institutions: Impact of the Escalating Crisis", JCMS, 50(2), 2012, pp. 85-98; M. Chang, "Understanding the Rules of European Economic Governance: Economics, Politics, and Wishful Thinking", Journal of European Integration, 34(3), 2012, pp. 297-303.

${ }^{8}$ C. Fasone, "European Economic Governance and Parliamentary Representation. What Place for the European Parliament?”, European Law Journal, 20(2), 2014, pp. 164-185.

9 R. Costello, R. Thomson, "The Distribution of Power among EU Institutions: Who Wins under Codecision and Why?", Journal of European Public Policy, 20(7), 2013, p. 1036.

${ }^{10}$ Ch. J. Bickerton, D. Hodson, U. Puetter, The New Intergovernmentalism. States and Supranational Actors in the Post-Maastricht Era, Oxford 2015. 
In the article, I will endeavour to answer the question about the role of the EP in shaping the MFF regulations for 2014-2020. In doing so, I will attempt to verify three hypotheses, which are proposed in scholarly literature on the subject of European parliamentarism. The first hypothesis is that although the legislative competences of the EP are rising steadily, this does not mean that the political power of this institution in the EU is also on the ascent. This applies especially to the relative power, i.e. to a comparison between the power of the EP and that of intergovernmental institutions. The latter also increase their power and gather informal clout in the EU. They retain their dominant political position in some areas (such as, e.g. fiscal policy), and in the time of crisis they may even grow in importance. If this suppositions were correct, it would mean that also the ultimate control over the final shape of the MFF negotiations would belong primarily to the intergovernmental institutions.

Secondly, I am going to consider whether the activity of the EP is not primarily used for the purposes of political legitimisation. If the Parliament does not increase its relative power in the EU, then perhaps its actions are merely a form of political show of strength? Perhaps the Parliament's basic role is to improve the political legitimacy for European integration. The abovementioned activity of the EP would therefore justify the systematic transfer of competences to the EU level in the eyes of the member state citizens. Within this approach, the role of the Parliament would be tantamount to political marketing. In the case of the budget negotiations that are the object of my paper, the hypothesis would be confirmed if it transpired that the EP had launched a major publicity operation in order to promote it's pro-European image and its willingness to continually support European integration, and in order to highlight the values of European solidarity and community. At the same time, the Parliament's real influence on the outcome of the negotiations would have been relatively modest.

Thirdly, I intend to verify the claim that the EP is a platform for the development of supranational elites. The functioning of this institution also brings to mind a "political cartel", in which the common interests of the political establishment are sometimes more important than the rivalry between party factions that differ in programme and agenda-related matters in accordance with their voters' preferences. This would mean that the EP does not seem to be a "majoritarian institution", whose workings would reflect, e.g. those of democratic institutions in the member states. For instance, the EP does not engage in programme-related deliberations on fiscal policy between the members of the parliamentary majority and the opposition according to clear majority criteria. In fact, it is just the opposite: the Parliament seems more often than not to be guided by common institutional interest and by concern for the interests of the pro-European political elite (regardless of party divisions.) Should this hypothesis prove correct, a similar attitude should also be in evidence during the MFF negotiations. The attitude could be manifested, e.g. in attempts to increase the competences of the Parliament in 
comparison to other European institutions with respect to the budget determination procedure.

In the remaining part of the article I am going to offer a review of scholarly literature on the EP that has bearing on the three hypotheses outlined above. Then, I will discuss the negotiations on the MFF 2014-2020, drawing primarily on source documents and in-depth interviews with selected participants of this process, representing the EP and other European institutions. The analysis will allow me to formulate my conclusions and prove (or disprove) my research hypotheses.

\section{A critical analysis of the development of EU parliamentarism}

The European Parliament plays an increasingly important role in the EU law making. It owes its dominant role primarily to the fact that it is elected in direct elections (ever since 1979), and its position in the legislative process was gradually strengthened in subsequent years. Its role was further increased by the Lisbon Treaty with its introduction of the ordinary legislative procedure (OLP, formerly the codecision) as the main method of adopting the regulations between the Council and the Parliament. It is estimated that this procedure applies to 85\% of EU law and over $86 \%$ of the entire legislation that is adopted with the participation of the $\mathrm{EP}^{11}$.

The expansion of the Parliament's powers is achieved in two ways. Firstly, its position grew thanks to the provisions of successive treaties, and thus thanks to the will of the member states. Secondly, the Parliament's position was also strengthened as a result of informal inter-institutional rivalries at the EU level, mainly between the EP and the Council (and also with other intergovernmental bodies). These rivalries are rooted in the ambitions of the parliamentary elites, who aim to increase their power hold on the EU arena. The growing role of the EP is the result of legislative negotiations undertaken with representatives of national governments, who quite often agree to systemic concessions that increase the powers of the Parliament in exchange for immediate legislative gains. These case-by-case legislative practices are over time perpetuated and formalized by relevant legislation (including subsequent amendments of the Treaty) ${ }^{12}$.

11 A. Maurer, Parlamente in der EU, Constance 2012, p. 139.

${ }^{12}$ H. Farrell, A. Héritier, "Formal and Informal Institutions under Codecision: Continuous Constitution-Building in Europe", Governance, 16(4), 2003, pp. 577-600; H. Farrell, A. Héritier, "Codecision and Institutional Change", West European Politics, 30(2), 2007, pp. 285-300; A. Héritier, Explaining Institutional Change in Europe, Oxford 2007; C. Moury, "Explaining the European Parliament's Right to Appoint and Invest the Commission", West European Politics, 30(2), 2007, 367-391. 
The Treaty changes, which in recent years have steadily increased the role of the Parliament, result, at least partially, from the self-interest of the MEPs themselves and from pursuit of their institutional agendas. But it is the representatives of the member states who undoubtedly play the chief role in the process. It is they who have the final say on the actual amount of power granted to the Parliament. According to Joseph Weiler, the growth of the competences of the EP is not synonymous with its gaining real power in the EU (especially in comparison with other actors $)^{13}$. Weiler claims that the Parliament's growth of power is compensated for by the simultaneous strengthening of intergovernmental institutions, especially the European Council. On the other hand, empirical study by Rory Costello and Robert Thompson suggests that when the OLP is applied, the Parliament has only about $20 \%$ of the political strength of the Council ${ }^{14}$. Other studies show that after the EU enlargement in 2004 and when using the same legislative procedure, the EP has only a 9 to $11 \%$ impact on the final content of legislation (assuming that the Council's impact is $100 \%)^{15}$. This reality is far removed from the vision implied in the formal separation of powers, where the codecision procedure gives both institutions comparable levels of political influence ${ }^{16}$.

The explanation of this seeming discrepancy lies predominantly in the so-called trilogue, which increases the power of the Council in the legislative process. The trilogue is an informal procedure that involves meetings of politicians from the Council and the EP who are especially competent in the matter concerned, with the participation of representatives of the Commission. The purpose of the meetings is to achieve a compromise regarding the regulations in question before commencing formal proceedings in the EP. Thus, the trilogue procedure contributes to the enactment of a law after the first reading. According to scholars, up to $80 \%$ of all legislation that is subject to OLP is first considered during trilogue meeting ${ }^{17}$. Interestingly, the Council's advantage is also visible during other stages of the OLP. The procedure is culminated by the negotiations in the so-called conciliation committee that includes the representatives of the Council and the Parliament. A thought-provoking study that analysed almost all relevant cases in the years 1993-2012 clearly shows that in

${ }^{13}$ J.H.H. Weiler, "Federalism Without Constitutionalism: Europe's Sonderweg”, [in:] The Federal Vision. Legitimacy and Levels of Governance in the United States and the European Union, ed. K. Nicolaidis, R. Howse, Oxford 2001, p. 55.

${ }^{14}$ R. Costello, R. Thomson, op. cit., p. 1032

${ }_{15} \mathrm{R}$. Thomson, Resolving Controversy in the European Union. Legislative Decision-Making Before and After Enlargement, Cambridge 2015, p. 207. 9-36.

${ }^{16}$ G. Tsebelis, G. Garrett, Legislative Politics in the EU, "European Union Politics", 1(1), 2000,

${ }^{17}$ M. Kohler, "European Governance and the European Parliament: From Talking Shop to Legislative Powerhouse", JCMS, 52(3), 2014, p. 612. 
$70 \%$ of regulations, the solutions accepted were the ones favoured by government representatives ${ }^{18}$.

During the eurozone crisis, the role of the Parliament in European politics weakened demonstrably. This was especially visible with regard to anti-crisis measures that were in a large degree linked to fiscal policy pursued by the member states. Governments did not hasten to grant the Parliament new competences in this area. In fact, the opposite was true: they made a point of disregarding the Parliament's opinions when they launched new anti-crisis instruments (for example because some of the instruments were created outside the framework of Community law.) Although the European Parliament played a formal legislative role in relation to certain regulations (especially the so-called TwoPack and Six-Pack), its role was limited to endorsing previously prepared intergovernmental decisions ${ }^{19}$. This was achieved via informal arrangements that were arrived at using the inter-institutional trilogue procedure. As a result, the EP's involvement in the new economic governance procedures adopted during the crisis is only a token one. In most cases, the Parliament's only prerogative was the right to being informed, and the institution did not have any decisionmaking capabilities ${ }^{20}$. It appears that the "legitimising" rationale was the reason behind the decision to entrust the Parliament with the task of cooperating with national parliaments in the matters related to economic governance (and associated with the European Semester procedure). According to the scholars, the legal foundations for this cooperation are devoid of specific solutions, and thus likely to have little practical significance ${ }^{21}$. This means that the true nature of the above-mentioned cooperation is in fact more that of a political manifestation than of a real and meaningful decision-making action. Again, its purpose is the reduction of the perceived democratic deficit that is the result of the introduction of the European Semester, which reduces the influence of national parliaments on national fiscal policy.

The above-mentioned examples may suggest that the developments of the EU parliamentarism up to today may have only slightly contributed to the strengthening of the relative power of the EP (especially on fiscal matters), and that their nature is in fact more connected to political marketing. If such is indeed the case, then the motivation behind these changes would doubtlessly be the willingness to reduce the perceived "democratic deficit" and the desire to justify further

${ }^{18}$ F. Franchino, C. Mariotto, "Explaining Negotiations in the Conciliation Committee", European Union Politics, 14(3), 2013, pp. 345-346, 357.

${ }^{19}$ C. Fasone, op. cit., pp. 170-172.

20 The only exception was the introduction of the so-called Two-Pack veto opportunities (both by the EP and the Council) to the delegated acts made by the European Commission and undertaken in relation to the budget plans of Member States, and linked to the excessive deficit procedure. Cf. C. Fasone, op. cit., pp. 174-176, 179, 181.

${ }^{21}$ Ibid., pp. 177-178. 
enlargement of the competences of the European Union in the perception of the public opinion in the member states ${ }^{22}$.

The fact that the EP is very active in the spheres of publicity and political marketing doubtlessly has the same purpose: it is to strengthen the legitimisation of the political system at the European level. However, the reality of behind-thescenes negotiations would be hidden behind the catchwords of democracy and increased participation of the EU citizens in policy-making. In spite of these publicly avowed ideals, the vital decisions are still taken by a fairly elite group of European decision-makers. This elite is in fact sometimes compared to a political cartel ${ }^{23}$. The term involves blurring the traditional division line between leftist and rightist political parties in terms of programmes, and redefining the conflict in terms of political marketing and symbols. The cartel-like character of the European elite also underscores its basic solidarity (disregarding the party divisions) in order to defend their own interests. It seems self-evident that the political practice of the EP closely resembles the features of a cartel described above. Researchers point out to the convergence of views between the main factions, and to the increasingly more pronounced symbolic confrontation between the euroenthusiasts and eurosceptics. They also remark on the parliamentary elites preoccupation with the interests of their own institution ${ }^{24}$. As a result, the EP is not very effective as an arena for political debate between rival political group $s^{25}$. The growing convergence of views between the left and the right can be explained by the extant practice of forming the majority in Parliament. In several consecutive parliaments, the majority was formed by the same largest parties, i.e. the Christian Democrats and the Socialists $^{26}$. The "grand coalition" or the "mainstream" parties make most of the legislative and policy-related decisions in the Parliament and they also decide on the appointment of key positions ${ }^{27}$. For example, in the Sixth European Parliament, almost $65 \%$ of all votes were subject to collaboration between the Christian Demo-

${ }^{22}$ B. Rittberger, F. Schimmelfennig, "Explaining the Constitutionalization of the European Union", Journal of European Public Policy, 13(8), 2006, pp. 1148-1167; F. Schimmelfennig, "The Normative Origins of Democracy in the European Union: Towards a Transformationalist Theory of Democratization", European Political Science Review, 2(2), 2010, 211-233.

${ }^{23}$ R.S. Katz and P. Mair, “The Cartel Party Thesis: A Restatement”, Perspectives on Politics, 7(4), 2009, pp. 753-766.

${ }^{24}$ R. Rose and G. Borz, "Aggregation and Representation in European Parliament Party Groups”, West European Politics, 36(3), 2013, pp. 475, 490-491.

${ }^{25} \mathrm{M}$. Kohler, op. cit.

${ }^{26}$ In the eighth EP (elected in the 2014) coalition set up the two largest factions: the Group of the European People's Party (EPP or Christian Democrats) and the Progressive Alliance of Socialists and Democrats (S\&D or Socialists).

${ }^{27}$ S. Hix and B. Høyland, "The Political System of the European Union", 3rd ed., Basingstoke 2013, p. 145; A. Kreppel, "The European Parliament and Supranational Party System: A Study in Institutional Development", Cambridge 2002; P. Hausemer, "Participation and Political Competition in Committee Report Allocation: Under What Conditions Do MEPs Represent Their Constituents?", European Union Politics, 7(4), pp. 2006, 505-530. 
crats and the Socialists ${ }^{28}$. These two political groups vote unanimously on the most controversial issues and they are also in accord on such matters as the legal harmonisation of the European market and broadening the powers of the $\mathrm{EP}^{29}$.

\section{The process of negotiating the Multiannual Financial Framework 2014-2020}

The process of negotiating the MFF for 2014-2020 started as early as in 2007, when the European Commission initiated public consultations and analytical work in this area. In 2011, it submitted the first draft of a Council regulation laying down the $\mathrm{MFF}^{30}$. That was the beginning of a three-year period of political negotiations. Then, a year later, in mid-2012, the Commission presented a revised version of the legislative proposal for a regulation laying down the multiannual framework ${ }^{31}$. The revised version was prepared because of the need to take into account the accession of Croatia into the EU, and also because it proved necessary to incorporate new statistical data pertaining to estimated revenues and budget expenditures and related calculations of maximum financial allocations for individual member states.

The next stage of work on the MFF involved sustained negotiations between member states. They lasted the longest of all (about two years) and were full of dramatic twists an turns, which is evidenced by the fact that the taking of final decisions was postponed many times (the specially convened summits of the European Council of July, October and December 2012 all ended in failure.) The final agreement was only reached as late as in February $2013^{32}$. The conclusions determined the level of financial commitments and payments broken down into the basic categories of the EU budget and divided year by year, and they also listed the range of contributions to the budget on the part of individual countries alongside a comprehensive catalogue of exemptions and rebates. It is worth noting that these financial arrangements were not substantially changed in the course of subsequent negotiations between the EU institutions. This situation demonstrates that the main decisions on the next financial perspective were essentially taken by the European Council. In spite of the fact that this body has no formal legislative powers (also with regard to the MFF), it wields the real political power in the EU.

${ }^{28}$ S. Hix and A. Noury, "After Enlargement: Voting Patterns in the Sixth European Parliament”, Legislative Studies Quarterly, 34, 2009, p. 165; R. Thomson, op. cit., p. 121.

${ }^{29}$ R. Thomson, op. cit., pp. 111, 130.

${ }^{30}$ European Commission, Proposal for a Council Regulation laying down the Multiannual Financial Framework for the years 2014-2020, COM(2011) 398 final, Brussels, 29.6.2011.

${ }^{31}$ European Commission, Amended proposal for a Council Regulation laying down the Multiannual Financial Framework for the years 2014-2020, COM(2012) 388 final, Brussels, 6.7.2012.

${ }^{32}$ European Council, Conclusions, EUCO 37/13, Brussels, 8.2.2013. 
It should also be noted that the final agreement, reached at the highest international level, and signed by the heads of state or government of the member states in February 2013, included a number of non-financial issues, that however have great significance for the spending and management of EU funds ${ }^{33}$. All these matters were included in the package negotiated during the summit of the European Council, and thus it was very difficult to change them in later negotiations with the EP. This, despite the fact that these issues went beyond the financial framework and should therefore be subject to another legislative procedure (the ordinary legislative procedure rather than consent), that gives the Parliament slightly larger influence over legislation. In the course of subsequent negotiations, the EP repeatedly drew attention to this problem and demanded more respect for its powers and thus sought to increase its political influence over issues related to the MFF regulations ${ }^{34}$.

The next stage of work on the MFF 2014-2020 involved the interinstitutional negotiations pursued by the Council with the European Commission and the EP. They were difficult, especially for Parliament, because the essential decisions had already been taken by the governments of the member states. This happened despite the fact that the Parliament warned the intergovernmental bodies not to take final financial decisions without consulting the Parliament first and without negotiating entire legislative packages with $\mathrm{it}^{35}$. These appeals promised to be a skilful negotiation tactic on the part of the EP, because their goal was to maximise the political influence of the Parliament in a long-term perspective. But for all their brilliance, the appeals were unsuccessful: in June of 2013 the representatives of the Commission, the Council and the Parliament reached a political agreement on the legislative package. After the summer break, in November 2013, the Parliament expressed its formal consent for the MFF, and in December 2013 the Council finally adopted the regulation ${ }^{36}$.

The Parliament was very active during the financial negotiations regarding the framework for 2014-2020. Even before the official Commission proposal, it was the first institution to present its own position regarding the next budget period of the $\mathrm{EU}^{37}$. The basis for the position was a report of the SURE Committee, a spe-

${ }^{33}$ European Council, op. cit.

${ }^{34}$ European Parliament, Resolution of 13 March 2013 on the European Council conclusions of 7/8 February 2013 concerning the Multiannual Financial Framework (2012/2803(RSP)).

${ }^{35}$ European Parliament, Resolution of 13 June 2012 on the Multiannual Financial Framework and own resources $(2012 / 2678(\mathrm{RSP}))$.

${ }^{36}$ Council, Regulation (EU, EURATOM) no 1311/2013 of 2 December 2013 laying down the Multiannual Financial Framework for the years 2014-2020, Official Journal of the European Union, L347, 20.12.2013, 884-891.

${ }^{37}$ European Parliament, Resolution of 8 June 2011 on Investing in the future: a new Multiannual Financial Framework (MFF) for a competitive, sustainable and inclusive Europe (2010/2211(INI)). 
cial EP committee established as early as $2010^{38}$. The representatives of the Parliament tried to keep the informal talks running, both with the representatives of the Commission and with the successive national presidencies (and therefore with the Council's negotiators $)^{39}$. The Parliament also made a number of important resolutions concerning the budget framework. Perhaps the most important among them was the resolution of 23 October 2012 that strongly criticised the Commission's proposal to freeze budget ceilings on the level from 2013, specified in the financial framework that was applicable back then ${ }^{40}$. This proposal was seen as a result of the Commission's bowing to the pressure of some member states ${ }^{41}$. Another equally momentous resolution was one in which the Parliament vocally criticised the results of the intergovernmental negotiations of February 2013 and proceeded to enumerate a set of conditions which the governments would need to fulfil in order for the Parliament to grant its consent to the new financial network ${ }^{42}$. In this way, the Parliament began its informal negotiations with the Council, concluded three months later by the signing of an interinstitutional agreement. When one compares this period of the negotiations to the two-year discussion in the intergovernmental institutions, it seems evident that the former had a markedly less heated atmosphere.

It appears that the Parliament was not an equal partner for the representatives of the Council ${ }^{43}$. Its negotiating position was weakened by the behaviour of the European Council and it was the latter that, after difficult negotiations, settled the most important decisions. After this, the Parliament could only resort to vetoing the intergovernmental proposals, but this action could prove very harmful for a variety of reasons. The veto made it possible to adopt a provisional budget based on the spending plan for 2013, but this could be seen only as a stopgap measure: it provided the financial resources, but did not solve the problem of the lack of regulations that would be necessary to implement EU policies and approximately 70 redistributive programmes for the new budgetary period. The starting point for the adoption of all of sectoral legislation was the regulation on the MFF. In addition, the Parliament's veto could be confusing for the public, since the MEPs themselves repeatedly pointed to the need for the adoption of the EU budget dur-

${ }^{38}$ SURE Committee, Activities and Documents, European Parliament 2009 - 2014, Strasbourg 2011.

39 Interview 9/2014; Kölling, M. and C. Serrano Leal, "An analysis of the agreement on the Multiannual Financial Framework 2014-2020", Working Paper, Elcano - Royal Institute, 2, 12.2.2014, p. 16.

${ }^{40}$ European Parliament, Resolution of 23 October 2012 in the interests of achieving a positive outcome of the Multiannual Financial Framework 2014-2020 approval procedure (COM(2011)0398 - $\operatorname{COM}(2012) 0388-2011 / 0177($ APP)).

${ }^{41}$ Interview 8/2014.

42 European Parliament, Resolution of 13 March 2013, op. cit.

${ }^{43}$ Interview 11/2014. 
ing the economic crisis ${ }^{44}$. The threat of complete paralysis of EU expenditure was thus very dangerous for the economy, and also for the functioning of the Brussels administration itself, and for many EU institutions, including the EP. One should also remember that the public opinion in the member states was influenced in the most part by the national governments, and that the impact of the Parliament's resolutions on the opinions of the general public can be seen as negligible. In the event of a veto, the Parliament's explanations and justifications of its decision would probably have less chance of being heard than the attacks of national politicians, especially the eurosceptics. In addition, it would be difficult to convince the taxpayers that it is the EP, rather than the national parliaments, that should make decisions regarding the allocation of their money. All these considerations lead to the fact that the intergovernmental institutions had more political legitimacy with regard to the matter, which further increased their informal power over the MFF.

The above-mentioned factors meant that the results of these relatively short negotiations between the Council, the Parliament and the Commission upheld most of the governments' decisions. The adjustments and amendments were of secondary importance, and sometimes were just token gestures. Many of them had a symbolic character, and were introduced for the purposes of political marketing. In truth, they were no more than "face-saving gestures" on the part of the Parliament's negotiators.

The Parliament did not manage to change the intergovernmental decisions in two crucial matters. Firstly, the EP wanted to increase the financial framework significantly over the ceilings agreed on in perspective for 2007-2013 $3^{45}$. But in the end, the decisions of the European Council reduced the MFF by almost 4\%, and in some budget categories the reductions were even more significant (e.g. the funds for cohesion policy and agricultural policy). In the matter of the multiannual framework, the Parliament managed to achieve only a token increase in funding one of the EU programs ${ }^{46}$. Secondly, the Parliament wanted to introduce structural revenue reforms into the EU budget and, most importantly, to boost EU's own revenue ${ }^{47}$ and reduce member states' contributions to approximately $40 \%$ of financial income (while simultaneously reducing the number of rebates and exemptions enjoyed by individual countries $)^{48}$. Also in this matter, the Parliament did not manage to obtain any concessions from the representatives of the Council, barring a vague promise of setting up a special working group, who would investigate the issue in question. The results of this team's activities are

${ }^{44}$ European Parliament, Resolution of 23 October 2012, op. cit.

${ }^{45}$ European Parliament, Resolution of 13 June 2012, op. cit.

${ }^{46}$ The financing of the Fund for European Aid to the Most Deprived was increased of one billion euros from the European Social Fund, the sum which has no great importance in MFF scale.

47 The revenues of the EU budget include customs duties on goods imported from third countries, tariffs on agricultural products imported from third countries and revenues from VAT. All of them, however, are collected by Member States and (in some parts only) are transferred to the EU.

${ }^{48}$ European Parliament, Resolution of 13 June 2012, op. cit. 
slated to be presented by the Commission in 2016. It should also be noted that the financial package negotiated in the European Council simply abounds in rebates and exemptions for individual countries, even though its ostensible purpose should be culling exceptions and inconsistencies from the system.

The Parliament also failed in its attempts to shorten the financial perspective period to five years and synchronize it with the EP terms of office. The aim of this operation was to strengthen the MEPs' political legitimacy to make decisions on the MFF by creating a stronger link between the budget procedure and the EP elections. However, the governments of most countries were opposed to this idea because they did not want to allow the MEPs insert themselves too much in financial decision-making. Yet another manifestation of the same attitude on the part of the member states was the attempt to limit the Parliament's powers during the negotiations surrounding the perspective for 2014-2020. There are a lot of examples of actions taken in order to achieve this goal, starting from the refusal to grant MEPs access to certain documents, through attempts to exclude some topics from the negotiation agenda ${ }^{49}$, to the inclusion in the financial regulation of many legislative issues that should be included in sectoral regulations, adopted under a different legislative procedure, which, as I mentioned above, would give the Parliament greater decision-making powers ${ }^{50}$. The Parliament also failed to block the attempts of many governments to push more and more financial categories outside the EU budget (including information on granted loans and financial guarantees). In effect, this practice limits the control and influence of the European Parliament over EU finances, and specifically over annual budgets ${ }^{51}$.

The MEPs see the introduction of a mandatory review of the MFF in the middle of the perspective period as their success ${ }^{52}$. But in truth, similar provisions were already present in conclusions of the European Council ${ }^{53}$, and were also incorporated in the previous perspective for 2007-2013. Another success was forcing the governments to cover the budget hole in 2013 to the amount of 11.2 billion euros. It was indeed a major achievement, though it is worth remembering that the total EU budget deficit accumulated from previous years exceeded 23 billion euros. In addition, the Parliament's action did not substantially change the existing practice of governments that were trying to lower the ceilings for both the multiannual perspective and the annual EU budgets below the level of their own statistically available resources. Another practice of the governments aimed at curbing the EU financing consists of reducing one's own contribution to the EU budget by

${ }^{49}$ Interview 5/2014.

${ }^{50}$ European Parliament, Resolution of 15 April 2014 on negotiations on the MFF 2014-2020: lessons to be learned and the way forward (2014/2005(INI)).

${ }^{51}$ Interview 6/2014.

${ }^{52}$ European Parliament, European Parliament approves EU's long-term budget (MFF) 20142020, European Parliament press release, 19.11.2013, http://www.europarl.europa.eu (access: 27.11.2014).

${ }^{53}$ European Council, op. cit. 
deducing from it the unused funds for a given financial year. It is associated with the tendency to avoid transferring the unused funds in a given year to the next EU financial year. During the negotiations, the Parliament sought to reverse this practice by increasing the so-called budgetary flexibility, but it succeeded only partially. The Parliament managed to increase the possibility to move expenditure in a flexible way between financial years and budget categories (in relation to both the so-called payments and commitments of the EU budget), although in a much more limited way than it had been initially proposed by the MEPs. The governments in turn managed to introduce global financial thresholds that limit the flexibility between given years and inserted other limitations for specific budget categories, which significantly limits the possibility of transferring the unused funds in the future ${ }^{54}$.

All in all, it seems clear that the power over determining the MFF for the years 2014-2020 belonged to intergovernmental institutions, especially the European Council, even though this body lacks formal legislative powers. The Parliament did not have too much say in the matter. The EP's most crucial demands were not included in the final regulations, and the revisions and amendments to intergovernmental decisions were only of secondary or symbolic importance. These observations confirm my first research hypothesis that in spite of the fact that for many years the formal powers of the EP have been increasing, its relative power in comparison with intergovernmental bodies has not been growing commensurably (especially in relation to fiscal policy).

Let us now consider my second research hypothesis, relating to the marketing efforts of the Parliament. The EP's activities in the sphere of publicity and political marketing have undoubtedly been numerous and were initiated well before the official start of the budget negotiations. A visible manifestation of the Parliament's publicity agenda were the resolutions that addressed the topic of the budget negotiations. They demonstrated the MEPs' clearly pro-European stance. The MEPs attitude was connected with the desire to further promote European integration, including the implementation of EU flagship projects such as the Lisbon strategy, and with the desire to counteract the economic crisis that could check the progress of integration. In the opinion of the MEPs, a large multiannual framework would contribute to an ambitious programme of European growth that would include economic recovery, elimination of poverty and unemployment and strengthening of the Union's foreign policy and its position on the international arena ${ }^{55}$. The MEPs repeatedly stressed that the EU budget should be constructed in accordance with the principle of solidarity and should be a quest for the "European added value" ${ }^{15}$. At the same time, they criticized the self-serving attitude of governments,

${ }^{54}$ European Parliament, An Introduction to the EU's Multi-annual Financial Framework, European Parliament Background, 18.11.2013, http://www.europarl.europa.eu (access: 27.11.2014).

${ }_{55}$ European Parliament, Resolution of 13 June 2012, op. cit.

${ }^{56}$ European Parliament, Resolution of 23 October 2012, op. cit. 
who were on the lookout for financial gain and who were "poisoned by the logic of 'fair returns' instead of being driven by the logic of the European added-value" 57 . The message coming from the Parliament was also connected to the Parliament's attempts to boost its public profile and present itself as an institution that proposes solutions for specific problems of EU citizens, e.g. related to the eurozone crisis.

It is worth noting that the Parliament's resolutions made use of the crisis rhetoric not only in order to justify more spending (and thus ensure economic growth in the strategic time horizon,) but also in order to fulfil other demands of the Parliament, aimed at strengthening the institution's political role in the budgetary process. The resolutions referred to the reality of the crisis, but their intended audience were the EU citizens, whom the Parliament was addressing, speaking to them directly, across the national governments. In many cases the Parliament's pro-European message was in stark contrast with the political tendencies of the national governments. The EP wanted to highlight the fact that it is an institution representing the citizens of the EU and that as such, it should have a greater influence over the decisions regarding budget spending and budget control.

Unfortunately, the Parliament's publicity efforts (though quite considerable), very often did not reach citizens of European member states. They were almost completely overshadowed by the ongoing debates in the member states. The debates were shaped by the attitudes of national governments and by their references to the national interest and by pandering to national voters (and taxpayers.) It coincided with the dearth of public debate on the European level, which was only limited to the EU institutions and think tanks. It was very hard for the MEPs' voices to be heard on the public arena in the member states, where they were easily overshadowed by nation-centric rhetoric. As a consequence, the political position of governments in budget negotiations grew even stronger. All these observations must lead to a conclusion that the function of the Parliament in the process of determining the MFF largely consisted of publically declaring its pro-European commitment and its willingness to represent citizens of the European Union, so it was in fact no more than a political marketing campaign. These publicity activities were only marginally effective both in terms of impact on the public opinion (and building a quasi-federal relationship between the Parliament and the EU citizens) and in terms of accumulation of political power by the Parliament at the EU level.

It is worth noting that the MEPs' arguments often referenced the need to increase parliamentary scrutiny of budget expenditure at the EU level and even the need to promote democracy in the European Union ${ }^{58}$. The EP also voiced a strongly federalist creed and suggested that budget revenues from member stated contributions should be converted to EU own revenue sources that are to a larger

${ }^{57}$ European Parliament, Resolution of 23 October 2012, op. cit.; European Parliament, Resolution of 15 April 2014, op. cit.

${ }^{58}$ European Parliament, Resolution of 23 October 2012, op. cit.; European Parliament, Resolution of 13 March 2013, op. cit. 
extent supervised by European institutions. All these demands and suggestions were united by a common goal of increasing the role of the Parliament in the MFF decision-making procedure. These phenomena prove my third research hypothesis, which stipulated that the actions of the EP elites resemble those of a political cartel, more focused on its own self-interest than divided by programme differences between parliamentary groups or factions. The primary objective on the EP's agenda was to use the procedure for adopting the MFF in order to defend its own institutional interests in the confrontation with the Council of the European Union and the European Council, and to increase its own powers (or at least to check the tendency to limit them in an informal way).

Interestingly, the Parliament in its successive resolutions presented an essentially unified political front, and therefore did not show the differences between political factions. The resolutions were adopted by the largest parliamentary groups (primarily by the EPP, S\&D and ALDE) ${ }^{59}$. The Parliament did not become an arena of major political controversy regarding the MFF. Such internal divisions occurred mainly at meetings of the Council of European Union and the European Council, and stemmed from electoral politics on the member state level. This shows that "democratic politicisation," based on programme-related differences and disputes was mostly limited to the national level and to intergovernmental institutions. The Parliament tried to present a more unified position, and it was largely defending its own institutional interests in competence disputes with intergovernmental institutions.

\section{Conclusion}

The negotiation process of the MFF for 2014-2020 is an attention-worthy case study that shows the actual role of the EP in the European Union. In this article I have tried to demonstrate that the power of the Parliament in the process of shaping the MFF is clearly inferior to that of intergovernmental institutions. The Parliament has taken a number of informal initiatives (that by definition are not described in legal procedures) that aimed to increase its political influence on the budget negotiations. However, it turned out that the European Council had much more informal power in the negotiations, and as a consequence the Parliament failed to achieve its major political objectives. It seems that in fact it only managed to secure minor or symbolic concessions. Nonetheless, the EP was very active in the field of political marketing, often referencing the principle of solidarity and other European values and the "European added value" of the EU budget. In this way, the Parliament fulfilled its function of legitimizing the EU political system, justifying gradual transfer of competencies in the integration process from member states to the European institutions. Thus understood, the

\footnotetext{
${ }^{59}$ ALDE - The Alliance of Liberals and Democrats for Europe.
} 
progress of integration does not lead to increase in the EP relative power. In fact, with respect to financial and budget-related matters, the development of integration led primarily to increased power of the EU intergovernmental institutions and also of the countries that are net contributors to the EU budget.

Even though the Parliament plays a legitimatizing role in the process of deciding the EU budget, it is difficult to castigate the MEPs for hypocrisy (or accuse them of the so-called institutionalized hypocrisy ${ }^{60}$. The latter term is used to denote empty gestures that have solely propagandistic value, i.e. are supposed to be manifestations of Europeanism, but are in fact futile and are not to achieve any meaningful institutional goals. Meanwhile, the behaviour of the parliamentary elite demonstrates a clear tendency to increase their powers in the procedure for determining the MFF. It could even be said that the elites seem to push towards a parliamentary federation and further strengthening European democracy. The majority of the Parliament consistently defended its own vision of integration, and spoke in favour of a large EU budget that could be seen as a method of fighting the economic crisis, conditioning growth and increasing the competitiveness of the EU economy, as well as its international position. The Parliament presented a vision of the European Union that is in stark contrast with the self-serving approaches demonstrated by the governments that oftentimes bowed to the pressure of eurosceptic groups who clamoured for maximising the particular country's gains. Regrettably, the governments' particularist attitudes hindered the smooth functioning of the EU and reaching towards the ambitious objectives outlined in "Europe 2020" strategy. Through its actions, the EP became a sui generis guardian of the Union's financial system and thus also a keeper of Europe's credibility and commitments. At the same time, the parliamentary elites were defending their own institutional interests in a way that resembles a behaviour of a political cartel.

\section{References}

Bickerton Ch.J., D. Hodson U. Puetter, The New Intergovernmentalism. States and Supranational Actors in the Post-Maastricht Era, Oxford 2015.

Bukovansky M., "Institutionalized Hypocrisy and the Politics of Agricultural Trade", [in:] Constructing the International Economy, ed. R. Abdelal, M. Blyth, C. Parsons, Ithaca 2010, pp. 68-90.

Chang M., "Understanding the Rules of European Economic Governance: Economics, Politics, and Wishful Thinking", Journal of European Integration, 34(3), 2012, pp. 297-303.

Costello R., Thomson R., "The Distribution of Power among EU Institutions: Who Wins under Codecision and Why?", Journal of European Public Policy, 20(7), 2013, pp. 1025-1039.

Council Regulation (EU, EURATOM) no 1311/2013 of 2 December 2013 laying down the Multiannual Financial Framework for the years 2014-2020, Official Journal of the European Union, L347, 20.12.2013, pp. 884-891.

${ }^{60}$ M. Bukovansky, Institutionalized Hypocrisy and the Politics of Agricultural Trade, [in:] R. Abdelal, M. Blyth, C. Parsons (eds.), Constructing the International Economy. Ithaca 2010, 68-90. 
De Wilde P., "Politicisation of the EU Budget: Conflict and the Constraining Dissensus", West European Politics, 35(5), 2012, pp. 1075-1094.

Dinan D., "Governance and Institutions: Impact of the Escalating Crisis", JCMS, 50(2), 2012, pp. 85-98.

European Commission, Proposal for a Council Regulation laying down the Multiannual Financial Framework for the years 2014-2020, $\operatorname{COM(2011)~} 398$ final, Brussels, 29.6.2011.

European Commission, Amended proposal for a Council Regulation laying down the Multiannual Financial Framework for the years 2014-2020, COM(2012) 388 final, Brussels, 6.7.2012.

European Council, Conclusions, EUCO 37/13, Brussels, 8.2.2013.

European Parliament, Resolution of 8 June 2011 on Investing in the Future: A New Multiannual Financial Framework (MFF) for a Competitive, Sustainable and Inclusive Europe (2010/2211(INI)).

European Parliament, Resolution of 13 June 2012 on the Multiannual Financial Framework and Own Resources (2012/2678(RSP)).

European Parliament, Resolution of 23 October 2012 in the interests of achieving a positive outcome of the Multiannual Financial Framework 2014-2020 approval procedure (COM(2011)0398 $\operatorname{COM}(2012) 0388$ - 2011/0177(APP)).

European Parliament, An Introduction to the EU's Multi-annual Financial Framework, European Parliament background, 18.11.2013, http://www.europarl.europa.eu (access: 27.11.2014).

European Parliament, European Parliament approves EU's Long-term Budget (MFF) 2014-2020, European Parliament press release, 19.11.2013, http://www.europarl.europa.eu (access: 27.11.2014).

European Parliament, Resolution of 13 March 2013 on the European Council Conclusions of 7/8 February 2013 concerning the Multiannual Financial Framework (2012/2803(RSP)).

European Parliament, Resolution of 15 April 2014 on Negotiations on the MFF 2014-2020: Lessons to be Learned and the Way Forward (2014/2005(INI)).

Farrell H., A. Héritier, "Formal and Informal Institutions under Codecision: Continuous Constitution-Building in Europe", Governance, 16(4), 2003, pp. 577-600.

Farrell H., A. Héritier, "Codecision and Institutional Change", West European Politics, 30(2), 2007, pp. 285-300.

Fasone C., "European Economic Governance and Parliamentary Representation. What Place for the European Parliament?", European Law Journal, 20(2), 2014, pp. 164-185.

Franchino F. and C. Mariotto, "Explaining Negotiations in the Conciliation Committee", European Union Politics, 14(3), 2013, pp. 366-387.

Grosse T.G., Changing the Integration Model: On the Fiasco of the Neo-functional Vision of the Crisis, unpublished manuscript, 2016.

Grosse T.G., "Overcoming the Crisis in the Economic and Monetary Union", Przeglad Europejski, 1, 2016, pp. 28-50.

Hausemer P., "Participation and Political Competition in Committee Report Allocation: Under What Conditions Do MEPs Represent Their Constituents?", European Union Politics, 7(4), 2006, pp. 505-530.

Héritier A., Explaining Institutional Change in Europe, Oxford 2007.

Hix S. and B. Høyland, The Political System of the European Union, 3rd ed., Basingstoke 2013.

Hix S. and A. Noury, "After Enlargement: Voting Patterns in the Sixth European Parliament", Legislative Studies Quarterly, 34, 2009, pp. 159-174.

Hodson D., Governing the Euro Area in Good Times and Bad, Oxford 2011.

Hooghe L. and G. Marks, "A Postfunctionalist Theory of European Integration: From Perspective Consensus to Constraining Dissensus”, British Journal of Political Science, 39(1), 2009, pp. 1-23.

Katz R.S. and P. Mair, “The Cartel Party Thesis: A Restatement”, Perspectives on Politics, 7(4), 2009, pp. 753-766. 
Kohler M., "European Governance and the European Parliament: From Talking Shop to Legislative Powerhouse", JCMS, 52(3), 2014, pp. 600-615.

Kölling M. and C. Serrano Leal, "An Analysis of the Agreement on the Multiannual Financial Framework 2014-2020", Working Paper, Elcano - Royal Institute, 2, 12.2.2014.

Kreppel A., The European Parliament and Supranational Party System: A Study in Institutional Development, Cambridge 2002.

Majone G., "From Regulatory State to a Democratic Default", JCMS, 52(6), 2014, pp. 1216-1223.

Maurer A., Parlamente in der EU, Constance 2012.

Moury C., "Explaining the European Parliament's Right to Appoint and Invest the Commission", West European Politics, 30(2), 2007, pp. 367-391.

Puetter U., “Europe's Deliberative Intergovernmentalism: The Role of the Council and European Council in EU Economic Governance”, Journal of European Public Policy, 19(2), 2012, pp. 161178.

Rittberger B., F. Schimmelfennig, "Explaining the Constitutionalization of the European Union", Journal of European Public Policy, 13(8), 2006, pp. 1148-1167.

Rose R. and G. Borz, "Aggregation and Representation in European Parliament Party Groups", West European Politics, 36(3), 2013, pp. 474-497.

Schimmelfennig F., "The Normative Origins of Democracy in the European Union: Towards a Transformationalist Theory of Democratization”, European Political Science Review, 2(2), 2010, pp. 211-233.

Schneider Ch.J., "Globalizing Electoral Politics. Political Competence and Distributional Bargaining in the European Union", World Politics, 65(3), 2013, pp. 452-490.

SURE Committee, Activities and Documents, European Parliament 2009-2014, Strasbourg 2011.

Thomson R., Resolving Controversy in the European Union. Legislative Decision-Making Before and After Enlargement, Cambridge 2015.

Tsebelis G. and G. Garrett, "Legislative Politics in the EU”, European Union Politics, 1(1), 2000, pp. 9-36.

Wehner J., "Institutional Constraints on Profligate Politicians: The Conditional Effect of Partisan Fragmentation on Budget Deficits", Comparative Political Studies, 43(1), 2010, pp. 208-229.

Weiler J.H.H., Federalism Without Constitutionalism: Europe's Sonderweg, [in:] The Federal Vision. Legitimacy and Levels of Governance in the United States and the European Union, ed. K. Nicolaidis, R. Howse, Oxford 2001. 